\title{
Nutrients in the Surface Waters of the Georgia- Florida Coastal Plain Study Unit, 1993-95
}

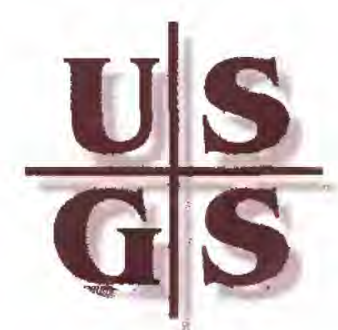

\section{By Lisa K. Ham}

\section{SUMMARY}

During 1993-95, water samples were collected at nine surfacewater sites in the Georgia-Florida Coastal Plain to determine nutrient concentrations. The sampling effort was part of the National Water Quality Assessment (NAWQA) Program by the U.S. Geological Survey.

Nutrient concentrations in nine surface-water sites within the study area were relatively low compared to nationwide nutrient concentrations. The major dissolved nitrogen species in most of the surface-water sites was organic nitrogen. Among the data collected at these nine sites, the higher values could be attributed to agricultural and urban land use practices, degrading plant and animal material from forest and wetland areas, point-source discharges, or runoff from poultry and dairy farms.

Nitrate concentrations in two of the nine rivers were highest when flows were lowest, indicating contributions from ground-water discharge to the rivers and influence from point-source discharges. At four sites nutrient concentrations increased during increases in discharge and decreased during decreases in discharge, suggesting a flush of nonpoint source contributions followed by dilution.

\section{INTRODUCTION}

The Georgia-Florida (GAFL) study unit (fig. 1) of the National Water Quality Assessment (NAWQA) Program encompasses about $62,000 \mathrm{mi}^{2}$ (square miles) in the southeastern United States, mostly in the Coastal Plain physiographic province. The population of the study area was 9.3 million in 1990. Urbanized areas account for 4.4 percent of the land use in the study area. Forest and agricultural areas are the most common land uses in the study area, accounting for 48 and 25 percent of the study area, respectively.

The environmental setting of the GAFL study unit has been described in a report by Berndt and others (1996) which includes a description of the important environmental influences on water quality




in the study area. A report by Hatzell and others (1995) described the surface-water sampling network in the context of these environmental influences and laid the ground-work for a design to evaluate data gathered during the study. Historical nutrient data and long-term trends in surface water in the study area were evaluated by Ham and Hatzell (1996).

This report examines nutrients in surface waters sampled as part of the high intensive sampling phase (1993-95) of the GAFL NAWQA Program. The sampling design was intended to account for largeand small-scale spatial variations, and temporal variations in nutrient concentrations of the study area. During the high intensive phase of the GAFL Program, nine surface-water sites were sampled regularly (monthly or weekly) for nitrate plus nitrite as nitrogen (hereafter referred to as nitrate), ammonia as nitrogen, organic nitrogen, and total phosphorus. These sites, called fixed sites, were selected based on drainage area, land use characteristics, and land resource provinces. The fixed sites are located on Tucsawhatchee Creek, Turnpike Creek, Altamaha River, Little River, Withlacoochee River, Suwannee River, Middle Prong St. Marys River (Middle Prong), Lafayette Creek, and Bullfrog Creek (fig. 1). Several of these basins are nested within one another: Tucsawhatchee and Turnpike Creeks are within the Altamaha River Basin and Little and Withlacoochee Rivers are within the Suwannee River Basin (fig. 1). In addition, 27 sites were sampled twice during 1994 (in May and June, the growing season) as part of a synoptic study to determine the spatial variability of nutrient concentrations in the study area. Due to the limited scope of this report. synoptic data collected at the nine fixed sites are included to evaluate the integrity of the synoptic sampling.

\section{Figure 2}

Land Use and Dissolved Nutrient Concentrations Among the Nine Fixed Sites
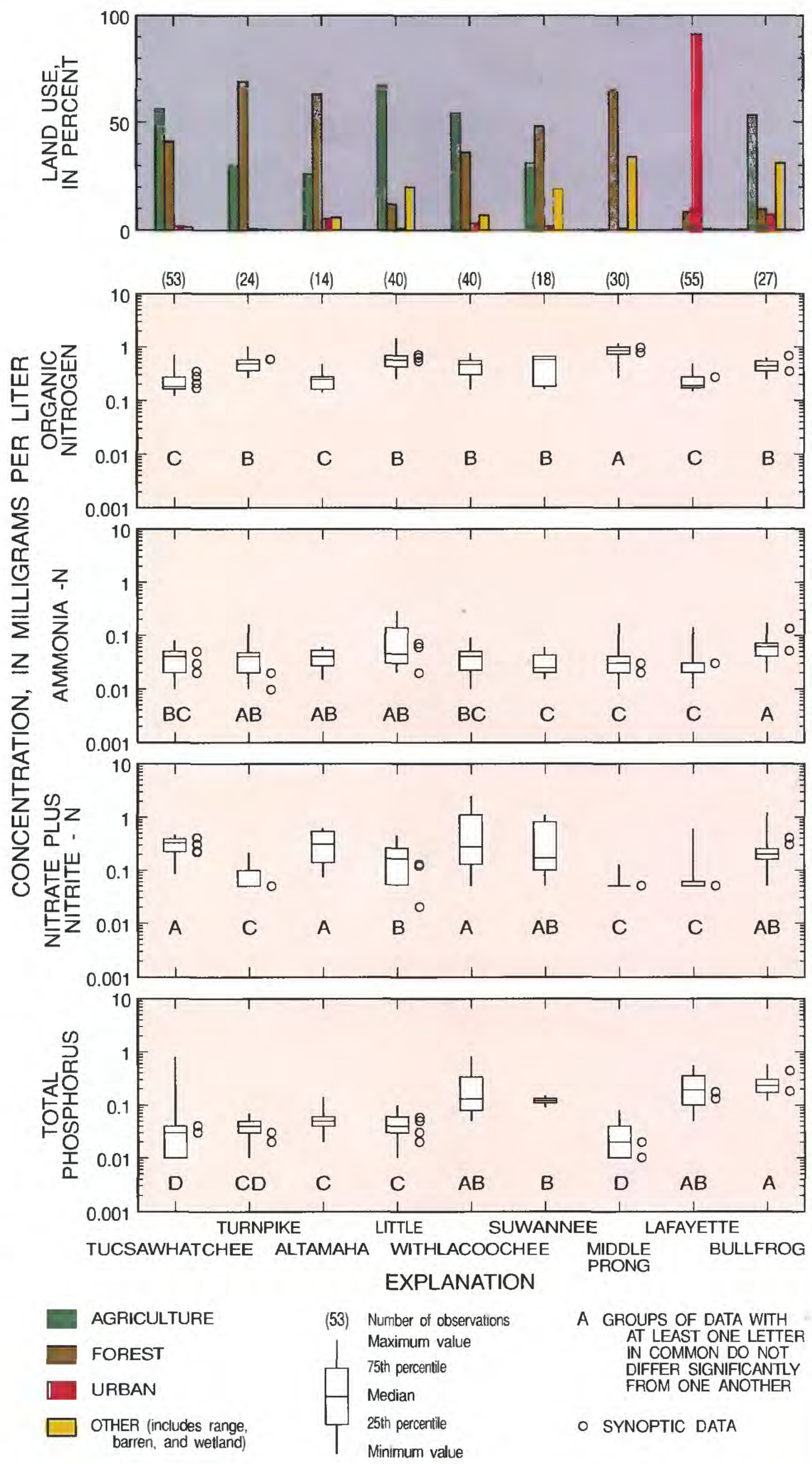

A GROUPS OF DATA WITH AT LEAST ONE LETTER IN COMMON DO NOT DIFFER SIGNIFICANTLY FROM ONE ANOTHER

- SYNOPTIC DATA 
A major criterion for the selection of the fixed-site network was based on the percentage of the major land uses in each basin (fig. 2). Land use is derived from digital data from 1972-78 (U.S. Geological Survey, 1986), updated with 1990 population estimates (Hitt, 1994) and might not represent current conditions. The Bullfrog Creek Basin is predominantly agriculture (53 percent), but in recent years, suburban development has increased. The Little River (67 percent agriculture) and Tucsawhatchee Creek (56 percent agriculture) Basins represent agricultural land use, the Lafayette Creek Basin (91 percent urban) represents suburban land use, and forested areas are represented by Middle Prong ( 65 percent forest) and Turnpike Creek (69 percent forest) Basins (fig. 2). The Altamaha, Withlacoochee, and Suwannee River sites are integrator sites that represent large basins with a mosaic of land uses (fig. 2). Tucsawhatchee Creek, Turnpike Creek, Little River, Middle Prong, Lafayette Creek, and Bullfrog Creek are indicator sites that represent small basins with one or two predominant land uses.

A total of 120 quality assurance samples were collected and analyzed to verify analysis of the 317 regular and synoptic water-quality samples. Included in the 120 quality assurance samples were 66 samples to ensure proper equipment cleaning (equipment, field, and source solution blanks) and 54 samples to determine the reproducibility of sampling and laboratory procedures (replicates). Results showed that the cleaning, sampling, and laboratory procedures were acceptable.

\section{NUTRIENT CONCENTRATIONS}

Overall, nutrient concentrations among the nine surface-water sites within the GAFL study area (fig. 2) were relatively low compared to nationwide nutrient concentrations and showed little absolute differences. The median total- phosphorus concentration was $0.13 \mathrm{mg} / \mathrm{L}$ (milligram per liter) in United States rivers (1974-81) (Smith and others, 1987) and $0.11 \mathrm{mg} / \mathrm{L}$ in Florida streams (197087) (Friedemann and Hand, 1989). Only three of the nine fixed sites had median total-phosphorus concentrations equal to or exceeding the national median valueBullfrog Creek ( $0.23 \mathrm{mg} / \mathrm{L})$, Lafayette Creek $(0.17 \mathrm{mg} / \mathrm{L})$, and Withlacoochee River $(0.13 \mathrm{mg} / \mathrm{L})$. The median total nitrogen concentration was $1.2 \mathrm{mg} / \mathrm{L}$ in Florida streams (1970-87; Friedemann and Hand, 1989). All fixed sites had median total nitrogen concentrations below the Florida median concentration. The highest nutrient concentrations were in the Withlacoochee River and Bullfrog Creek; both basins include some urban areas. The lowest nutrient concentrations were in Middle Prong and Tucsawhatchee Creek.

At seven of the nine fixed sites in the study area, the major dissolved nitrogen species in surface water was organic nitrogen, which frequently is the case in Florida streams (Kaufman and Dysart, 1978). For the remaining two sites, Tucsawhatchee Creek and Altamaha River, the major nitrogen species was nitrate.

Although nutrient concentrations are low throughout the study area, differences exist in nutrient concentrations among the fixed sites. The nonparametric statistical approaches used in this report to determine differences in median nutrient concentrations among sites were the KruskalWallis and Tukey tests (level of significance was 0.05 ). The Kruskal-Wallis test was used to determine if constituent concentrations differed among the nine fixed sites. The Tukey test was used to determine which fixed sites differ from the others for each constituent. Concentrations at sites are significantly different unless they have at least one letter (A, B, C, or D) in common with one another (fig. 2).

Organic nitrogen concentrations were significantly higher at Middle Prong (median of $0.85 \mathrm{mg} / \mathrm{L}$ ) than at the other eight sites (fig. 2). Degrading plant and animal material from forest and wetland areas that cover a large part of the Middle Prong Basin could result in high organic nitrogen concentrations. Median organic nitrogen concentrations among the three sites within the Suwannee River Basin (Little, Withlacoochee, and Suwannee Rivers) were not significantly different. The variability indicated by the large interquartile range for the Suwannee River site $(0.47$ $\mathrm{mg} / \mathrm{L}$ ) may be due to the many springs contributing ground water with low organic nitrogen concentrations into the river system and surface runoff during high flow. Three of the nine sites had maximum organic nitrogen concentrations equal to or above $1.0 \mathrm{mg} / \mathrm{L}$ - Little River (maximum of $1.5 \mathrm{mg} / \mathrm{L}$ ), Middle Prong $(1.2 \mathrm{mg} / \mathrm{L})$, and Turnpike Creek $(1.0 \mathrm{mg}$ / L). Synoptic data from the Tucsawhatchee Creek, Turnpike Creek, Little River, Middle Prong, and Lafayette Creek were similar to data collected during regular sampling; one of the two synoptic samples collected at Bullfrog Creek had a higher organic nitrogen concentration than had occurred during regular sampling.

Although significant differences in ammonia concentrations existed among the nine fixed sites, the medians were low and ranged from $0.02 \mathrm{mg} / \mathrm{L}$ at Lafayette Creek, which is predominantly urban, to $0.06 \mathrm{mg} / \mathrm{L}$ at Bullfrog Creek, which is an agricultural area changing to urban. Both creeks are representative of suburban environments. Concentrations of ammonia in synoptic samples collected at Turnpike Creek and Little River were at or below the minimum ammonia concentrations detected during regular sampling.

The relatively high nitrate concentrations at the Tucsawhatchee Creek, Withlacoochee River, and Suwannee River sites may be attributed to agricultural land use practices. High concentrations at the Altamaha River and Bullfrog Creek sites may be attributed to urban land use practices as also indicated by the relatively high ammonia concentrations at these two sites (fig. 2). Nitrate concentrations were significantly lower in the Lafayette Creek (median of $0.05 \mathrm{mg} / \mathrm{L}$ ), Middle Prong $(0.05 \mathrm{mg} / \mathrm{L})$, and Turnpike 
Creek $(0.05 \mathrm{mg} / \mathrm{L})$ than in the other six basins in the study area. Maximum nitrate concentrations exceeded $1.0 \mathrm{mg} / \mathrm{L}$ at three sites-Withlacoochee River (maximum of $2.5 \mathrm{mg} / \mathrm{L}$ ), Bullfrog Creek (1.2 $\mathrm{mg} / \mathrm{L}$ ), and Suwannee River $(1.1 \mathrm{mg} / \mathrm{L})$. One synoptic sample collected at Little River had a concentration below the minimum nitrate concentration during regular sampling. Two other synoptic samples had nitrate concentrations near the median.

The highest median total-phosphorus concentrations occurred at Bullfrog Creek (median of $0.23 \mathrm{mg} / \mathrm{L}$ ), Lafayette Creek $(0.19 \mathrm{mg} / \mathrm{L})$, and Withlacoochee River $(0.13 \mathrm{mg} / \mathrm{L})$. The maximum totalphosphorus concentrations were at the Withlacoochee River $(0.82 \mathrm{mg} / \mathrm{L})$ and Tucsawhatchee Creek $(0.80 \mathrm{mg} / \mathrm{L})$ sites. The lowest median total-phosphorus concentrations occurred at Middle Prong $(0.02 \mathrm{mg} / \mathrm{L})$, Tucsawhatchee Creek $(0.03 \mathrm{mg} / \mathrm{L})$, and Turnpike Creek $(0.04 \mathrm{mg} / \mathrm{L})$. In general, basins containing more urban land tended to have higher median total-phosphorus concentrations, whereas basins containing more forest land tended to have lower median totalphosphorus concentrations. Synoptic and regular samples collected at the nine sites had similar total-phosphorus concentrations.

\section{VARIABLITY OF NUTRIENT CONCENTRATIONS}

High flows commonly occurred at the fixed sites from January 1994 through March 1995 and low flows commonly occurred from May through December 1993 (fig. 3). The discharges for the nested sites within the Altamaha River Basin (Turnpike and Tucsawhatchee Creeks and Altamaha River) had similar patterns. Discharges during periods of high flow were similar among the nested sites within the Suwannee River Basin

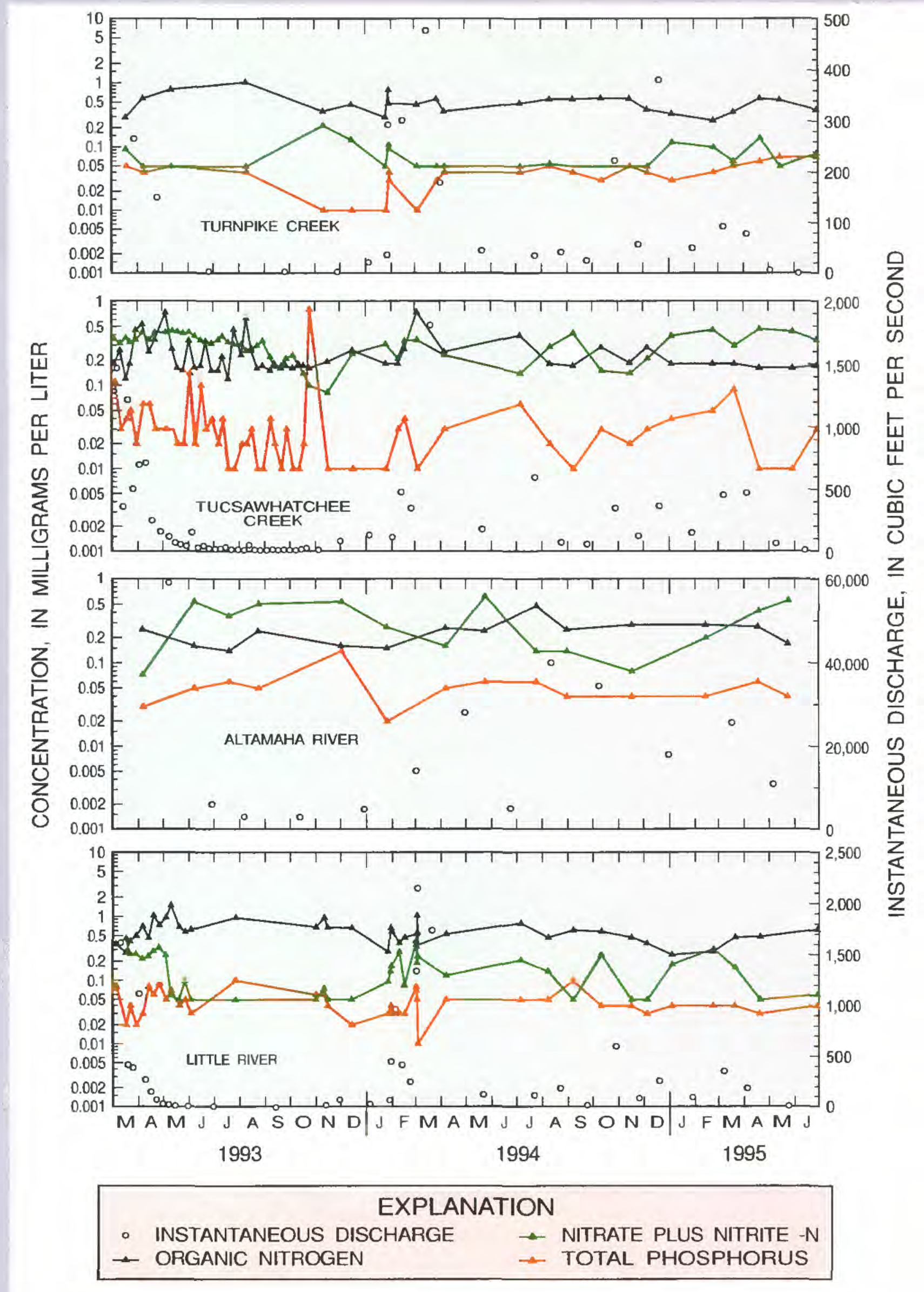

Figure 3

Instantaneous Discharge and Concentrations of Major Nutrients at the Nine Sites, 1993-95 


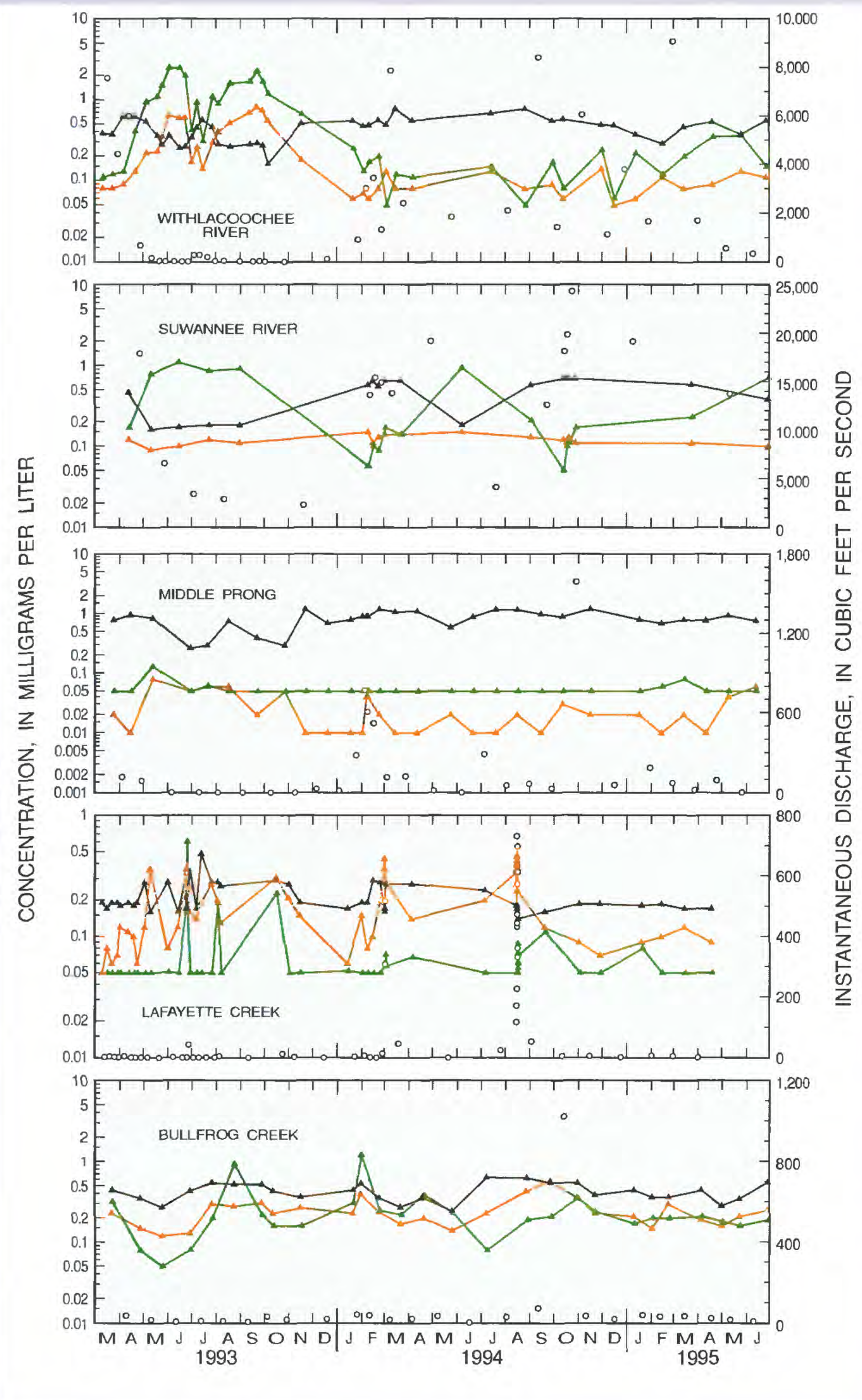

(Little, Withlacoochee. and Suwannee Rivers); however, discharge during periods of low flow at the Suwannee River site had less variability than the tributaries because of the influence of ground water recharge to the Suwannee River during low flow.

Average daily mean discharges were 11 to 46 percent higher at seven of the nine sites from March 1993 through June 1995 than the average daily mean discharge for the period of record (see table on next page). Only the Suwannee River and Middle Prong had daily mean discharges during the sampling period that were lower than their period of record daily mean discharges. During the sample-collection period, mean instantaneous discharges ranged from $18,290 \mathrm{ft}^{3} / \mathrm{s}$ (cubic feet per second) at Altamaha River to $61 \mathrm{ft}^{3} / \mathrm{s}$ at Bullfrog Creek and maximum discharges among the fixed sites ranged from $59,000 \mathrm{ft}^{3} / \mathrm{s}$ at Altamaha River to $477 \mathrm{ft}^{3} / \mathrm{s}$ at Turnpike Creek. The six smallest sites (Tucsawhatchee Creek, Turnpike Creek, Little River, Middle Prong, Lafayette Creek, and Bullfrog Creek) with drainage areas less than $200 \mathrm{mi}^{2}$ had one or more periods of no flow during the sample-collection period. Water-quality samples were not taken during periods of no flow.

Nutrient concentrations were compared to instantaneous discharge values using the Kendall tau correlation test. A relationship between discharge and nutrient concentration was considered to be significant if the $p$-value was less than 0.05 and the Kendall tau correlation coefficient was greater than 0.65 (Helsel and Hirsch, 1992). If the Kendall tau coefficient was negative then the nutrient decreased with an increase in discharge, indicating dilution as the controlling factor on nutrient concentrations. If the coefficient was positive then the nutrient concentration increased with increased discharge, indicating contribution of nutrients from runoff. 


\section{Description of Surface-Water Data}

\begin{tabular}{|c|c|c|c|c|c|c|}
\hline \multirow[b]{2}{*}{ Basin } & \multirow[b]{2}{*}{ Site } & \multirow{2}{*}{$\begin{array}{c}\text { Drainage } \\
\text { area at } \\
\text { sampling } \\
\text { site } \\
\left(\mathrm{mi}^{2}\right)\end{array}$} & \multicolumn{2}{|c|}{$\begin{array}{l}\text { Mean of daily discharges } \\
\qquad\left(\mathrm{ft}^{3} / \mathrm{s}\right)\end{array}$} & \multicolumn{2}{|c|}{ Difference in mean of daily discharges } \\
\hline & & & $\begin{array}{l}\text { Period of } \\
\text { record }\end{array}$ & $\begin{array}{c}\text { Sampling } \\
\text { period } \\
\text { (March 1993- } \\
\text { June 1995) }\end{array}$ & $\begin{array}{c}\text { Between sample } \\
\text { period and } \\
\text { period of record } \\
\left(\mathrm{ft}^{3} / \mathrm{s}\right)\end{array}$ & $\begin{array}{l}\text { Between } \\
\text { sample period } \\
\text { and period of } \\
\text { record } \\
\text { (percent) }\end{array}$ \\
\hline Altamaha River & $\begin{array}{l}\text { Tucsawhatchee Creek near } \\
\text { Hawkinsville, Ga. } \\
(02215100)\end{array}$ & 163 & 166 & 226 & +60 & +36 \\
\hline Altamaha River & $\begin{array}{l}\text { Turnpike Creek near McRae, } \\
\text { Ga. }(02216180)\end{array}$ & 49 & 55 & 79 & +24 & +44 \\
\hline Altamaha River & $\begin{array}{l}\text { Altamaha River near Everett } \\
\text { City, Ga. }(02226160)\end{array}$ & 14,000 & 13,737 & 17,903 & $+4,166$ & +30 \\
\hline Suwannee River & $\begin{array}{l}\text { Little River near Ty Ty, Ga. } \\
(02317797)\end{array}$ & 129 & 168 & 164 & -4 & -2 \\
\hline Suwannee River & $\begin{array}{l}\text { Withlacoochee River near } \\
\text { Quitman, Ga. (02318500) }\end{array}$ & 1,480 & 1,183 & 1,727 & +544 & +46 \\
\hline Suwannee River & $\begin{array}{l}\text { Suwannee River near Bran- } \\
\text { ford, Fla. }(02320500)\end{array}$ & 7,800 & 7,075 & 7,937 & +862 & +12 \\
\hline St. Marys River & $\begin{array}{l}\text { Middle Prong St. Marys } \\
\text { River near Taylor, Fla. } \\
(02229000)\end{array}$ & 125 & 111 & 91 & -20 & -18 \\
\hline Lafayette Creek & $\begin{array}{l}\text { Lafayette Creek near Talla- } \\
\text { hassee. Fla. }(02326838)\end{array}$ & 10 & 9 & 10 & +1 & +11 \\
\hline Bullfrog Creek & $\begin{array}{l}\text { Bullfrog Creek near } \\
\text { Wimauma, Fla. }(02300700)\end{array}$ & 29 & 41 & 47 & +6 & +17 \\
\hline
\end{tabular}

Using the aforementioned criteria, only 4 out of 36 possible correlations of instantaneous discharge with nutrient concentrations were significant. All of these were at large basins - nitrate (Kendall tau coefficient of -0.656) on the Altamaha River; nitrate (-0.816) and total phosphorus (-0.656) on the Withlacoochee River; and organic nitrogen $(0.656)$ on the Suwannee River. The Altamaha River is the largest basin in both area and discharge among the fixed sites. which may account for the dilution effects. In addition, the Altamaha and Withlacoochee Rivers could be influenced by pointsource discharges which could result in negative correlations between discharge and nutrient concentrations. Smaller basins may not have a correlation between discharge and nutrient concentrations because of the periods of little or no flow.

Although not statistically significant. the relationship between discharge and nutrient concentrations can indicate factors influencing nutrient concentrations. Nitrate concentrations in the Suwannee and Withlacoochee Rivers were highest when flows were lowest, indicating influence from point-source discharges.

Nutrient concentrations increased at Tucsawhatchee Creek, Turnpike Creek, Little River, and Lafayette Creek sites during increases in discharge and nutrient con- centrations decreased during decreases in discharge, suggesting a flush of nonpoint source contributions followed by dilution.

\section{NUTRIENT YIELDS}

Nonpoint sources of nutrients are generally higher in agricultural areas (fertilizers and animal manure). Point sources (sewage effluent) of nutrients are higher in urban areas, although some point sources (paper mill effluent) occur in undeveloped areas. Wastewater discharges within the study area in 1990 were estimated at nearly 1,215 million gallons per day (Marella and Fanning, 1996). 

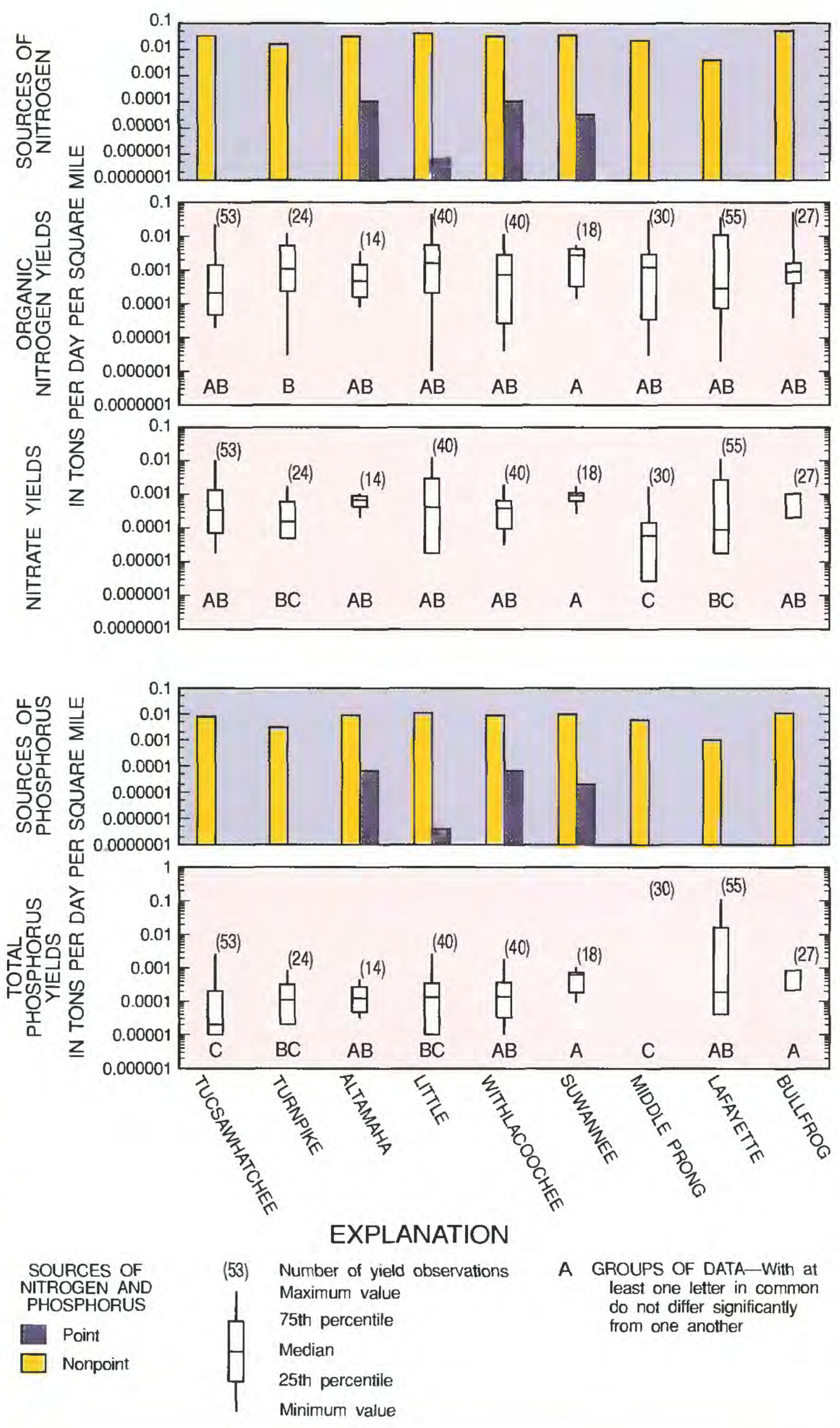

Figure 4

Nutrient Yields and Sources of Nutrients Among the Nine Fixed Sites
Because basin sizes vary among the nine fixed sites, nutrient yields, expressed in tons per day per square mile of basin $\left[(\right.$ tons $\left./ \mathrm{d}) / \mathrm{mi}^{2}\right]$, are used instead of loads or concentrations in order to make comparisons among fixed sites. Yields for point sources of nitrogen and phosphorus in figure 4 were calculated from wastewater discharge (Marella and Fanning, 1996), whereas yields from nonpoint sources were calculated from estimated inputs of fertilizer, manure, septic tanks, and atmospheric deposition (Berndt, 1996, p. 12). Yields for nutrients in stream water are based on instantaneous discharges measured at the time of sampling and are general estimates that may not reflect the actual amounts being transported in each basin. The total amount of nitrogen and phosphorus entering a river basin from point and nonpoint sources varied among the fixed sites. The Kruskal-Wallis test was used to determine if nutrient yields differ among the fixed sites. The Tukey test was used to determine which fixed sites differ from the others for each nutrient.

Among the fixed sites, organic nitrogen yields were not significantly different, except that the yield at the Suwannee River site [median of $0.0028(\mathrm{ton} / \mathrm{d}) / \mathrm{mi}^{2}$ ] was significantly different from the yield at the Turnpike Creek site $\left[0.0011\right.$ (ton/d)/mi $\left.{ }^{2}\right]$ (fig. 5). The relatively high yield of organic nitrogen at the Suwannee River site may be due to the wetland headwaters and the poultry and dairy farms present in the basin. There were no significant differences in ammonia yields among the fixed sites. Nitrate yields were not significantly different among the fixed sites, except that median nitrate yields at the Suwannee River site $[0.0009$ (ton $\left./ \mathrm{d}) / \mathrm{mi}^{2}\right]$ were higher than at the Middle Prong site $\left[0.00006(\right.$ ton $\left./ \mathrm{d}) / \mathrm{mi}^{2}\right]$. Higher yields of total phosphorus occurred at the Bullfrog Creek and Suwannee River sites. Sources in these basins are phosphate mining operations and geologic formations containing phosphate. 


\section{REFERENCES CITED}

Berndt, M.P., 1996, Ground-water quality assessment of the Georgia-Florida Coastal Plain study unit--Analysis of available information on nutrients, 1972-92: U.S. Geological Survey Water-Resources Investigations Report 95-4039. 39 p.

Berndt, M.P., Oaksford, E.T., Darst, M.R., and Marella, R.L., 1996, Environmental setting and factors that affect water quality in the Georgia-Florida Coastal Plain study unit: U.S. Geological Survey Water-Resources Investigations Report 95-4268. $45 \mathrm{p}$.

Friedemann, Mark, and Hand, Joe, 1989, Typical water quality values for Florida's lakes. streams and estuaries: Tallahassee, Florida Department of Environmental Regulation, 23 p.

Ham. L.K.. and Hatzell, H.H., 1996, Analysis of nutrients in the surface waters of the Georgia-Florida Coastal Plain study unit, 1970-91: U.S. Geological Survey WaterResources Investigations Report $96-$ 4037, $67 \mathrm{p}$.

Hatzell, H.H., Oaksford, E.T., and Asbury, C.E., 1995, Sampling design and procedures for fixed surface-water sites in the Georgia-Florida Coastal Plain study unit, 1993: U.S. Geological Survey Open File Report 95-279, 16 p.

Helsel, D.R., and Hirsch, R.M., 1992, Statistical methods in water resources: Amsterdam, Elsevier, 522 p.

Hirsch, R.M., Alley, W.M., and Wilber, W.G., 1988. Concepts for a National WaterQuality Assessment Program: U.S. Geological Survey Circular 1021, 42 p.

Hitt, K.J., 1994, Refining 1970's land-use data with 1990 population data to indicate new residental development: U.S. Geological Survey Water-Resources Investigations Report 94-4250, $15 \mathrm{p}$.

Kaufman, M.I., and Dysart, J.E., 1978, Nitrogen, phosphorus, organic carbon. and biochemical oxygen demand in Florida surface waters, 1972: U.S. Geological Survey Water-Resources Investigations 78-43, $33 \mathrm{p}$.
Marella, R.L., and Fanning, J.L., 1996, National Water Quality Assessment of the Georgia-Florida Coastal Plain study unit - Water withdrawals and treated wastewater discharges, 1990: U.S. Geological Survey Water-Resources Investigations Report 95-4084, 75 p.

Smith, R.A., Alexander, R.B., and Wolman, M.G., 1987, Water-quality trends in the Nation's rivers: Science, March 27, 1987, v. 235 , p. 1607-1615.

U.S. Geological Survey, 1986, Land use and land cover digital data from 1:250,000and 1:100,000-scale maps: National Mapping Program Technical Instructions, Data Users Guide 4, 36 p.

Appreciation is extended to the following members of the NAWQA staff for collecting and processing the data discussed in this report:

$$
\begin{aligned}
& \text { Dariene Blum } \\
& \text { John Byrnes } \\
& \text { Robert Coffin } \\
& \text { Christy Crandall } \\
& \text { Greg Donley } \\
& \text { James Gagalis } \\
& \text { Alexander Gallagher } \\
& \text { Thomas Garside } \\
& \text { Rupert Heirs } \\
& \text { Richard Kelly } \\
& \text { Susan Lane } \\
& \text { Jonathan Martin } \\
& \text { Lori Peed } \\
& \text { John Pittman } \\
& \text { Alan Punshon } \\
& \text { Marlon Savarino } \\
& \text { Mark Zucker }
\end{aligned}
$$

\author{
For more information, please contact: \\ Project Chief \\ Georgia-Florida Coastal Plain Study Unit \\ U.S. Geological Survey \\ Suite 3015 \\ 227 North Bronough Street \\ Tallahassee, FL 32301
}

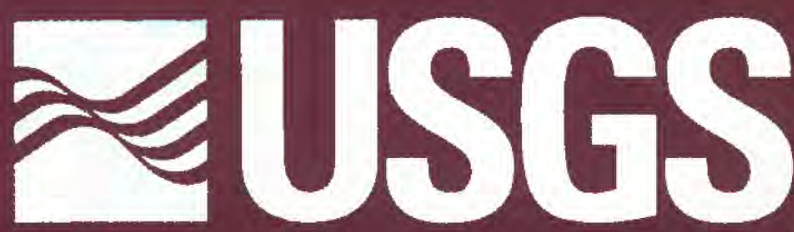

science for a changing world

\section{NATIONAL WATER-QUALITY ASSESSMENT PROGRAM}

The Georgia-Florida Coastal Plain is 1 of 20 study units started in 1991 as part of the USGS National Water-Quality Assessment Program. The purpose of the NAWQA Program is to assess the quality of a large, representative part of the Nation's waters (Hirsch and others, 1988). 